\title{
Dwelling Is a Key Idea in Traditional Residential Architecture's Sustainability: A Case Study at Yangwan Village in Suzhou, China
}

\author{
Fengyi Ji ${ }^{1,2}$ and Shangyi Zhou ${ }^{2, *}$ \\ 1 College of Urban and Environmental Sciences, Peking University, Beijing 100871, China; \\ jify0224@stu.pku.edu.cn \\ 2 School of Geography, Faculty of Geographical Science, Beijing Normal University, Beijing 100875, China \\ * Correspondence: shangyizhou@bnu.edu.cn
}

Citation: Ji, F.; Zhou, S. Dwelling Is a Key Idea in Traditional Residential Architecture's Sustainability: A Case Study at Yangwan Village in Suzhou, China. Sustainability 2021, 13, 6492. https://doi.org/10.3390/su13116492

Academic Editor: Nikos Salingaros

Received: 6 April 2021

Accepted: 30 May 2021

Published: 7 June 2021

Publisher's Note: MDPI stays neutral with regard to jurisdictional claims in published maps and institutional affiliations.

Copyright: (c) 2021 by the authors. Licensee MDPI, Basel, Switzerland. This article is an open access article distributed under the terms and conditions of the Creative Commons Attribution (CC BY) license (https:// creativecommons.org/licenses/by/ $4.0 /)$.

\begin{abstract}
Previous studies have failed to grasp the essence of traditional building habits responding to natural challenges. Therefore, contradictions arise between unified regulations protecting traditional residential architecture proposed by experts and the diverse construction transformation performed by locals. To resolve these contradictions, fieldwork was conducted in Yangwan, a famous village in South China. The traditional residential architectural characteristics in three periods were obtained and compared. Peirce's interpretation of the three natures of habit and Heidegger's dwelling help determine the essence of building habits. The logic in traditional residential architecture is analysed through the "four-layer integrated into one" framework (including the natural environment, livelihood form, institution and ideology), yielding the following results. (1) The characteristics of the residential architectural form change with local livelihood form, institution and ideology. Nevertheless, the process by which local residents think, judge and respond to natural challenges remains unchanged (Thirdness of Habit), forming the core of dwelling. (2) The characteristics of the architectural form are determined by the causal chain of "four-layer integrated into one". Stable causal chains are formed by the Thirdness of Habit, which represents people's initiative in addressing natural challenges. Therefore, the protection of traditional residential architecture should centre on dwelling and people's agency in response to the natural environment rather than on maintaining a unified physical form.
\end{abstract}

Keywords: traditional residential architecture; dwelling; thirdness of habit; protection and renewal

\section{Introduction}

Because previous studies have failed to grasp the essence of traditional building habits that responded to environmental challenges, contradictions between unified regulations regarding the protection of traditional residential architecture proposed by experts and the diversified construction transformation carried out by local residents have emerged in many countries worldwide. Across generations, people have accumulated much experience through interactions with the natural environment in living practice. This valuable experience embodies the wisdom of human-environment interaction [1]. It promotes the formation of building habits that continuously guide people's building behaviour and lead them to spontaneously care for and repair their houses. In modern society, however, modernity and official planning led by experts have limited the degree to which residents can participate in the process of building and repairing houses. The ICOMOS (International Council on Monument and Sites), which is devoted to the conservation of architectural heritage, believes that the "value and authenticity of architectural heritage cannot be based on fixed criteria" but also believes that the "value of architectural heritage lies in the integrity of all its components as a unique product of the specific building technology of its time" [2]. It also ignores that the formation of the characteristics of traditional residential architecture is a process including constant adaption to natural and social environment changes. 
As a result, residential architecture has become a physical form unrelated to the environment, causing two major conflicts between official planning and daily life. First, after modernity destroys traditional building habits, official planning pieces together the characteristics of traditional architectural forms to create a traditional cultural space but disconnects people from the material space. The development of human-environment interactions is hindered. Planning ignores the intimacy and familiarity that residents have with their daily living space, and the residents have the expectation and ability to improve their living conditions by themselves. It gradually alienates people from their houses, causing the destruction of traditional cultural heritage [3-5].

Second, the adaptability of traditional residential architecture to natural conditions and natural disasters may be neglected by unified planning. For example, a law in Malta forced people to construct row houses with front and back gardens, neglecting the fact that the row houses were conducive to thermal preservation but not suitable for the humid and hot climate in the central Mediterranean [6]. In another case, concrete slab-on-grade houses that could be conveniently moved and demolished were constructed in many states in the United States. However, they were not suitable for Louisiana, where floods occur frequently and the soil has a high viscosity. These concrete slab-on-grade houses were destroyed by the intense flooding produced by Hurricane Katrina, while traditional houses raised on wooden piles reappeared and the raised basement house form was developed. Both of the latter characteristics followed the principle of elevation to meet the local natural environment [7]. The application of the characteristics of vernacular architecture can also create a sense of belonging for displaced people in resettlement projects and provide a housing solution, avoiding the providers (government and designers) offering only lowcost and unified houses [8]. All these cases demonstrate the strong practical value of traditional residential architecture.

Two generally related disciplines have been unable to resolve the above two problems. Geographers mainly study traditional architecture by means of comparison, description and explanation. They focus on regional differences and the causes of the characteristics of traditional architecture while summarizing the rules and patterns in the differences and causes $[9,10]$. Most of them regard the cultural landscape, including traditional architecture, as the product of social constructs. Therefore, geographers attach importance to the social, historical and cultural background embodied in the cultural landscape to a higher degree [11], leading them to ignore the role of the natural environment [12]. In contrast, architectural scholars pay more attention to the interaction between architecture and the natural surroundings, hoping to obtain useful experience from the construction process [13]. In this way, contemporary architects make use of traditional structural characteristics to build energy-saving architecture without the help of modern equipment [14,15]. Although some studies believed that family financial status and the behaviour of residents had a stronger influence on household energy cost than the building structure [16], more research has emphasized the unilateral influence of the natural environment on architecture. In summary, recent studies fail to recognize that traditional residential architecture is the product of human-environment interactions. Furthermore, the rationality of the formation and change in architectural characteristics and building habits is not discussed, so official planning and practice lack a suitable basis.

Therefore, it is necessary to understand the essence of building habits from the perspective of human-environment interaction and regard the traditional residential architecture as a continuous adaption to the environment to understand the logic behind it. As the essence of building habits, the concept of dwelling helps us find the relationship between humans and the natural environment and clarify the essence of building habits. It can further clarify which characteristics of the traditional architectural form should be protected and updated. The characteristics of traditional architectural form are the materialized form of building habits; these can help us understand the concept of dwelling proposed by Heidegger from the perspective of geography, avoiding a sole emphasis on unique and monumental architecture [17]. Dwelling is the embodiment of harmonious human-environment interaction; 
it originates from human beings' continuous thinking and judging through long-term interaction with the natural environment. It is the build and care behaviours of the residents that lead the visible house to become a dwelling space. The process of understanding the realization of dwelling is also the process of discovering the Thirdness of Habit proposed by Pierce, which represents the spirit of residents who constantly think and judge to cope with natural challenges.

Through a comparison of the characteristics of the traditional architectural form in different periods in Yangwan Village, Dongshan Town, Suzhou City, China, this article finds that the architectural characteristics are constantly changing. However, the idea of using architecture's own structure to create a liveable environment remains stable. It is the main reason for the formation of the same characteristics, which can still meet the actual needs or realize people's sense of belonging and identity. Local and traditional materials and other available resources satisfy local residents' needs in simple and economic ways [18]. The characteristics of traditional architectural form are the identified cultural symbols of locals, so the building process becomes a way for locals to protect and preserve their religious identity and cultural belonging [19]. The different characteristics reflect the choices of local villagers after continuous thinking and judging (Thirdness of Habit) in a constant interaction with nature challenges over generations, and it is also the process of realizing dwelling. This process is in line with the requirements of contemporary society for the sustainable development of architecture. In future architectural practice worldwide, traditional architecture cannot only rely on methods of isolated protection, such as displays in museums or reconstruction after demolition. Dwelling, which provides a channel for human-environment interaction, can help human beings retain the essence of building habits and promote the sustainability of residential architecture in different regions. Thus, dwelling and the Thirdness of Habit should also become one of the criteria used to evaluate the sustainability of architectural practice.

\section{Literature Review: Dwelling and Building Habits}

The core of dwelling is harmonious human-environment interaction, and real architecture is a place that realizes dwelling. Heidegger noted that "dwelling", meaning staying and protecting, was the basic feature and the way of human existence [20]. The essence of dwelling is the preservation of the fourfold, that is, saving the earth, receiving the sky, awaiting the divinities and initiating mortals. Human beings live in the fourfold through dwelling, implying that the core of dwelling lies in the coordination between the human and natural environment, that is, not disturbing the order of the earth, conforming to the change in seasons, cooperating with divinities, and protecting the human until death. Building and dwelling happen simultaneously. Building is using techniques to build a material framework and integrate sky, earth, divinities and human into a material house to form a fourfold and realize dwelling [20]. The core of a building is to allow people to dwell, which protects the fourfold by bringing it into one object. Only when people dwell can people build [20]. Therefore, real architecture provides places for the fourfold and dwelling, and human beings stay or remain in the spaces of the fourfold through dwelling.

Dwelling is a way for people to understand human-environment interaction. Heidegger pointed out that only when human beings care for constantly growing things can dwelling be realized and protect the fourfold [20]. Dwelling is also an ongoing process. To cope with the changing environment, houses are constantly repaired and decorated. Familiarity with the environment can strengthen the connection between people and the environment. When the emotional connection between people and the environment is formed through constant interaction and human beings' thinking, the material house can be transformed into a living place, and dwelling will be realized at that time [21]. A person who has no emotional connection with his house cannot realize dwelling because he or she had nothing to do with the space or the things in the space [22]. It is the process of building and care that makes the house a dwelling space [23]. Seamon also emphasized the role of care and protection. He believed that the process of dwelling was intangible and that 
there was no need to define a physical index for it [24]. When people care about the place where they live, that place or a part of it becomes home. Planners should understand the environment of daily life as a dwelling space with vitality and significance to promote the vitality of space.

Architecture, together with human beings, is an organic part of the surrounding environment and a developing life form. When people are living in architecture, the interaction between them and the architecture encourages them to form new ideas and expressions. The process of changing architectural practice can be understood as the process of people coping constantly with a new environment. For example, immigrants tend to keep traditional habits in an unfamiliar environment and retain their own culture or identity by building [25]. In the process of building, architecture also shapes human beings, and then architecture is reshaped. Through constant thinking, human beings and architecture grow together [26]. Buttimer believed that dwelling was a way of living in harmony with the natural rhythm and that built architecture was a symbol of the daily interaction between human beings and the natural environment [27]. People are used to living in an environment close to nature, and this is conducive to people's sense of belonging in the architecture [28]. In the process of dwelling, cherishing and caring for architecture, the natural environment becomes an integral part of daily life. It is the material house that connects the inner world of a human being with the external environment and provides a place for communication between them [29].

Dwelling is also the essence and core of building habits. Building habits are the stable behaviour pattern of people in the process of building. Habit refers to a positive way of action that people generally adopt when they do things. It is a behaviour that can be acquired by posteriority and can repeat regularly with little or no thinking [30]. Peirce believed that phenomena could be recognized from the categories of Firstness, Secondness and Thirdness: Firstness is objective existence and the nature of phenomena; Secondness is the reflection upon Firstness and the action taken in response to it; and Thirdness is the intermediary between Firstness and Secondness [31]. According to the different characteristics of habit, it can be divided into three levels-the habit of feeling (Firstness), the habit of action (Secondness), the habit of thought (Thirdness) - that correspond to the three levels of the mind, that is, feeling, sensation of reaction and general conception, respectively.

The Thirdness of building habits, namely, the habit of thought, reflects the spirit of residents who constantly think and judge building measures to cope with natural challenges. This spirit, formed through long-term interaction with the natural environment, is the realization process of dwelling. The building habits originating from dwelling can be inherited only if we adhere to dwelling. Patra believed that the principle of dwelling was to adhere to the symbiotic relationship between humans and the natural environment, which has never changed [29]. For example, in Cyprus, from the coastal areas to the lowland areas and then the mountainous areas, the layout of traditional architecture became increasingly compact, and the number of stories gradually increased to cope with environmental changes, such as decreasing temperature, humidity and the available land [32]. What remained unchanged was that the locals always kept an active attitude to change the architectural layout to meet the natural environment. Most of the local residents in Xishuangbanna, China, used wooden boards and battens to build floors and walls, which were easy to take down and install, so that they could be dismantled during the flood season to prevent water erosion to the maximum extent [33]. After a flood, the original building materials could still be used, which showed the concept of dwelling.

On the one hand, changes in livelihood form, institution and ideology, as well as the continuous thinking of residents, have promoted changes in building habits. The change in these conditions is obviously faster than that in the natural environment. Moreover, habits are not stable or repetitive. Over a long period of time through constant thinking, human beings take initiatives and change their habits [34]; thus, human-environment interaction is promoted. The original residents of Palembang on Sumatra Island made a living by fishing and through river trade. They formed building habits involving the use 
of local materials and living near the river. As the area of the Musi River decreased and river pollution became more serious, roads gradually became the main traffic channels and trading places. With modernization, the original raft houses and high-rise houses gradually changed into unified terraced houses that gradually occupied wetlands, tidal areas and even rivers [35]. The traditional building habits around the Musi River were disrupted. In the Chittagong Hill Tracts of Bangladesh, the impact of modernization on the valley plain was far greater than that in the hilly area. The traditional architectural forms, building materials and spatial organization were abandoned by people in the valley plain and were replaced by modern unified houses [10].

On the other hand, the stability of the natural environment and the constant thinking of people resist changes in building habits. Although a habit is not unchangeable, a formed habit does not change quickly: it is constantly impacted and re-chosen after human thinking and judgement over the long term [36]. In general, humans only keep useful habits. First, the constant thinking of people promotes the inheritance of building habits. When Polish immigrants settled in London, they believed that the local houses could not meet the local natural environment. Given the same building materials and technologies as the locals, Polish immigrants constructed houses with large building massing, stable foundations and good heat preservation, which are the traditional building habits in Poland [37]. After young villagers in the desert of Egypt personally participated in the practice of constructing houses, they recognized the good ability of traditional building habits, such as using raw soil materials and mud brick masonry, to adapt to the desert climate. These young people spontaneously integrated traditional building habits with modern facilities during construction [38].

Second, the stability of natural elements, such as climate, topography, hydrology, natural disasters and resources, promotes the inheritance of building habits. Intertwined rivers in Thailand not only provide a cooling function but also bring floods. The rivers offered obvious advantages in waterway transportation, fishery and trade, so local residents constructed houses on wooden stilts along the river banks and even created floating houses on the water [39]. The Batan Islands in the northern Philippines are prone to intense wind. To prevent wind damage, local residents adjusted the orientation of their houses, and short sidewalls without windows were created to face the direction of the prevailing wind [40]. The hollow courtyard design of the traditional tube building in Vietnam created a natural ventilation corridor that also meets the need for social communication within the neighbourhood [41,42]. This building habit has been highly praised by modern architects. Due to the harsh natural environment in Siberia, the local people generally worshiped nature and all creatures. They carved sun symbols, horses, swans and flowers on the doors, under the roof, on the windows or as indoor wood carvings [43].

The constant adjustment and creation of building habits is a process of dwelling realization (Figure 1). Habits are the embodiment of human-environment interaction and the embodiment of daily life [44]. The specific architectural characteristic form that people choose to deal with natural challenges represents the Firstness of Habit. The natural environment then determines the primary goal of building and provides the basic needs for the formation of building habits (Secondness of Habit) through the Firstness of Habit. The application of the Secondness of Habit provides feedback, which promotes the process of constant thinking and judging, taking care and protecting (Thirdness of Habit). Then, the Thirdness of Habit in turn offers new ways of thinking about nature for the Firstness, forming new building measures to face natural challenges. The emergence of new building measures (Firstness of Habit) encourages people to further think and judge (Thirdness of Habit), contributing to the reselection of the building habits that are now being used (Secondness of Habit) and the stimulation of certain architectural characteristics again (Firstness of Habit). Tuan believed that habit was formed by repeated activities that gradually led the original purpose and means of activities to be forgotten [45]. We can return to the original intention of activities and self-existence only by constant thinking and judging in daily life. It also a way human beings return to dwelling. Dwelling 
is a changing, creating, opening, flowing process in which the three natures of habit influence each other [46]; it shows and maintains harmony between humans and the natural environment. The evolution of building habits is the process of realizing dwelling. The natural environment provides the foundation for the development of building habits, and constant thinking and judging are the bridges between the natural environment, building habits and dwelling.

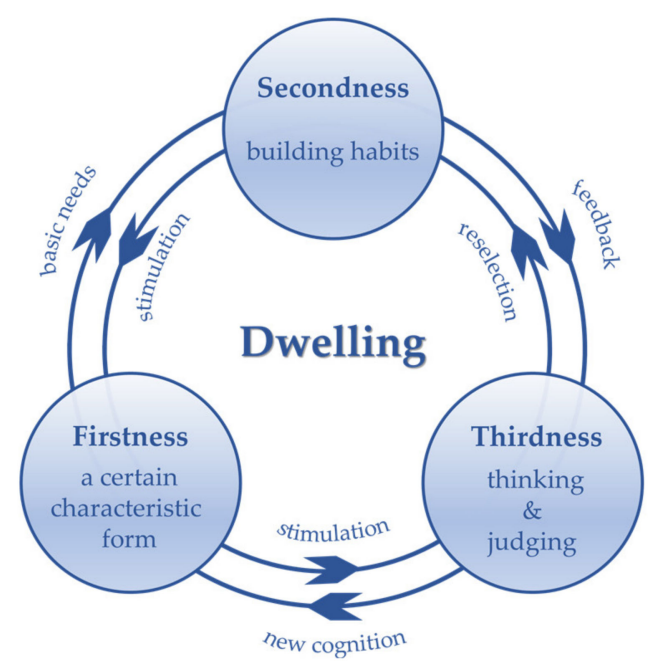

Figure 1. The relationship between dwelling and building habits. (Drawn by Fengyi Ji).

Previous studies have emphasized the modern application of the characteristics of traditional residential architecture [47-50] rather than inquiring or reflecting upon the causes and mechanisms driving both the stability and changes in the characteristics of traditional houses. As a product of human activities, residential architecture is building habits with a physical form. However, building habits are unstable, which inspires us to generalize and discover them through different forms in a wider space [51]. This article aims to determine how human beings cope with natural challenges in their interaction with the natural environment to ultimately realize dwelling. Dwelling is the essence of human-environment interaction, and it is in line with the requirements of contemporary society for sustainable architecture. In architectural practices all over the world, dwelling can offer a way for planners and residents to gain mutual understanding. It can also provide a reference for the renewal and protection of traditional residential architecture globally and for future building behaviour.

\section{Methodology}

\subsection{Study Area}

The study area of this article is Yangwan (see Figure 2), which was chosen for the following reasons. First, the natural environment has a significant impact on the characteristics of the residential architectural form in Yangwan. Yangwan has a typical subtropical monsoon climate characterized by hot summers, cold winters, and abundant precipitation changing with the seasons. Local residents commonly build high-rise Tianjing-style houses with narrow alleys for ventilation and avoidance of direct sunlight. Second, Yangwan is one of China's Historic and Cultural Villages. Compared with other villages in this area, Yangwan, known as the Museum of Ancient Architecture, has been less affected by tourism development. During the Ming and Qing Dynasties, the agriculture and handicraft industry developed well, and there were frequent business exchanges with other areas. The ancient architecture in Yangwan from the Ming and Qing Dynasties is well preserved, reflecting the typical characteristics of the traditional architectural form of Suzhou style. After the 1990s, with the improvement in villagers' living standards, European-style archi- 
tecture appeared in the village, especially along Lake Tai, and a contradictory landscape with both old and new houses was formed.
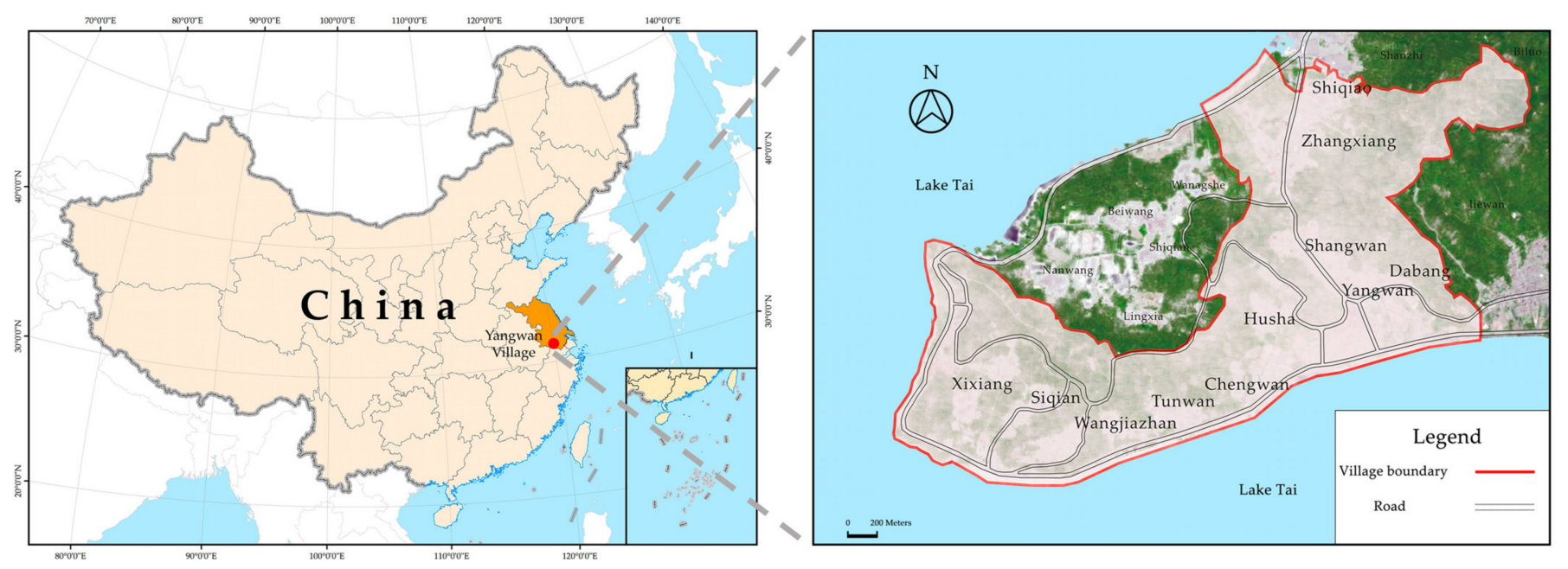

Figure 2. The location of Yangwan Village (Drawn by Fengyi Ji).

The current planning of Yangwan does not reflect the actual situation. In the core protection area of the planning, the height, building massing, appearance and colour of existing buildings are not allowed to change. Both newly built and rebuilt houses are expected to meet the unified requirements by using small building massing, "white walls and black roof tiles", wooden windows and doors, traditional roof ridges and so on [52,53]. The unified requirements prohibit "large building massing", which is the traditional residential architectural method used to cope with the hot and humid climate. Various means adopted by residents to cope with natural challenges have also been ignored. The planning regulations and most related studies focus on traditional residential architecture in the core planning area or on Cultural Relic Protection Units at all levels. Therefore, the architecture with a small scale outside the core area, which has a scattered distribution and unclear property rights, lacks sufficient protection. They have been subject to demolition, reconstruction, abandonment and collapse, resulting in conflicts between residents and scholars and between residents and planners.

\subsection{The Applied Methods of This Article}

Three research periods were identified to study the change in the characteristics of traditional residential architectural forms. The first period is before 1978 (including the Ming Dynasty, Qing Dynasty, Republic of China era and 1949-1978), which is the main period for the formation of the historical architectural features in Yangwan. Much of the architecture built in the first period is still in use today. It should be noted that the Land Reform implemented in 1950-1952 directly changed the ownership of property and the use rights of residential architecture, which led to many residents living and repairing the same house with different ideas. Due to the low level of productivity at that time, however, people were not able to significantly change the architectural characteristics. The second period is from 1978 to 2014. During this period, relevant protection planning had not yet been issued. With the progress of the Reform and Opening Up in China, the living standards of villagers had improved greatly, and houses became a symbol of wealth in people's minds. Villagers preferred to demolish old houses and build new counterparts suitable for modern life; they tended to adopt a European style or a modern style that was not consistent with the traditional architectural style in Yangwan. The third period begins in 2014. At this time, Yangwan became one of China's Historic and Cultural Villages, and special protection and development plans were issued that clearly defined the characteristics of new residential architecture. Although houses had been protected before 2014, becoming a Chinese Historical and Cultural Villages was a milestone for Yangwan, 
and the village began to strictly control and protect the characteristics of the residential architecture form.

The methodological framework is as follows (Figure 3): the fieldwork was conducted first to obtain data on the characteristics of the residential architectural form in Yangwan. We went to Yangwan to observe, measure and record the characteristics of the residential architectural forms built in different periods (Step 1). Twenty-one residential buildings with obvious characteristics were observed in detail. The orientation, number of floors, building materials, decorative patterns of the houses and so on were recorded, and specific data such as building height and width, wall thickness, angle of roof inclination, specifications of door and window were measured. We also obtained the locals' building experience, the perception of the natural environment, the evaluation of architectural features in different periods, and the evaluation of current planning through interviews. In addition, 12 residents, 4 local celebrities and 2 building workers were also interviewed. Based on the data obtained in the fieldwork, a contrastive analysis was carried out to determine whether people chose to keep or change their building habits in different situations. Through this contrastive analysis, the stable characteristics of residential architecture during different periods were also obtained (Step 2). Next, a framework based on the "four-layer integrated into one" concept (natural environment, livelihood form, institution and ideology) was used to discuss the complex causes that affect the stable inheritance of architectural characteristics and building habits. The generality of complex causal chains in different periods was also summarized through this process (Step 3). Finally, the Thirdness of building habits was found from the stable causal chains, and the Thirdness of building habits was also found to be the core of dwelling.

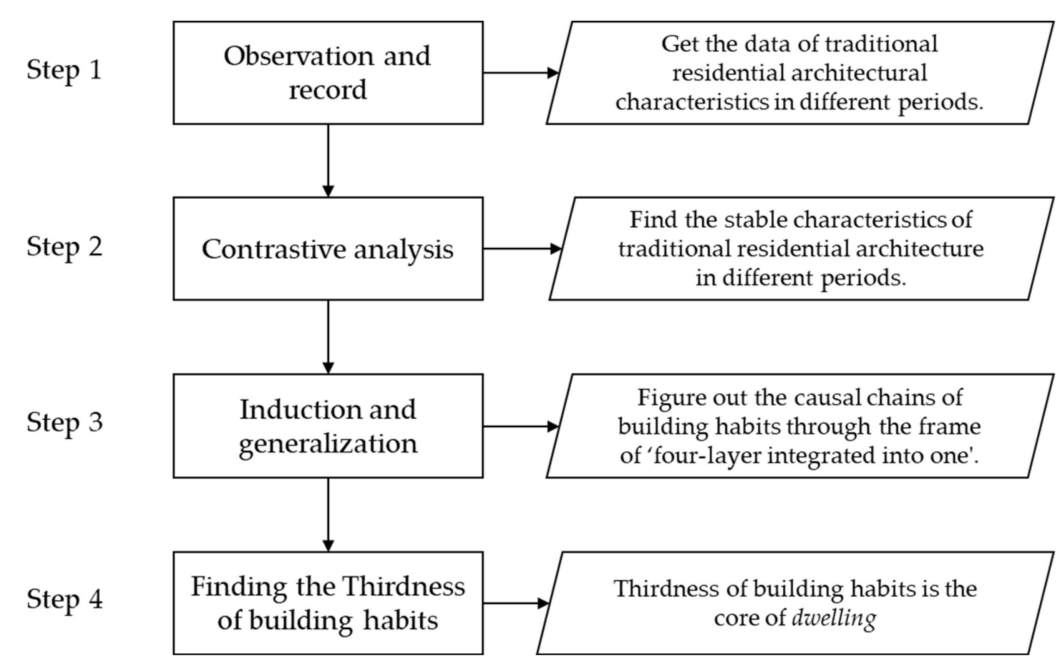

Figure 3. The methods applied in this article. (Drawn by Fengyi Ji.).

\section{Stability in Change: The Characteristics of Residential Architecture Forms in Different Periods}

\subsection{The Stable Characteristics of the Residential Architectural Form in Different Periods}

To cope with the environment, some characteristics of residential architecture in different periods (see Figures 4 and 5), such as the volume and foundation of architecture, the wall structure, the roof form and the building colour, showed a stable line of inheritance. First, the local residents retained the habit of building architecture characterized by multiple layers and large massing for ventilation given a hot and humid climate and to accommodate more people. Although the number of floors in the architecture increased from 1-2 in the first period to 2-3 in the second and third period, the height of each floor was always at least 3.2 metres. A greater floor height was conducive to ventilation, heat dissipation, and dehumidification and provided a comfortable living environment. Second, most of the residential architecture built in the second and third periods stopped using the spatial structure of the Tianjing style from the first period, and the courtyard style was more 
often adopted. However, the Tianjing yard was retained in some traditional architecture, and it still served the function of promoting ventilation, cooling and dehumidification. In addition, some residents of the original Tianjing houses had built modern brick concrete houses around the original site in the second and third periods (Figure 6). Compared with their newly built counterparts in the third period, the building structure and massing of houses in the second period saw no major changes. The main differences between them were in the choice of some materials and the house decoration styles.

The third retained characteristic, a row-lock cavity wall, was used from the first period to the second period because of its good thermal insulation performance and low price. It disappeared in the third period because of its poor stability. Fourth, the terrain of Yangwan varies greatly. An inclined courtyard foundation was convenient for adjusting the height of the courtyard to adapt to the topography and creating flat ground to facilitate construction. Moreover, underground ditches were usually laid inside the foundation to drain rainwater in a timely manner. In the third period, the application of permeable floor tiles decreased the practicability of underground ditches, which were gradually abandoned. Fifth, the Chinese gabled roof was retained in all periods, and the roof slope angles were maintained at 25-35 degrees. With improvements in the quality of waterproof materials, the average length of roof eaves dropped from $40-70 \mathrm{~cm}$ in the first period to $20-45 \mathrm{~cm}$ in the next two periods. Sixth, doors and windows were generally retracted inward to protect doors and windows from erosion by wind and rain. The inward retracted distance of windows was no more than $10 \mathrm{~cm}$, and windowsills were not horizontal but tilted down 10-20 degrees and provided space for drying shoes and clothes in sunny weather. Most importantly, the sloping windowsills could prevent rainwater from accumulating or flowing into the room. Seventh, the design of ventilation holes under the wall for ventilation and heat dissipation was retained in the second period. With improvements in building structure and materials and the application of air conditioning, this design was abandoned in the third period.

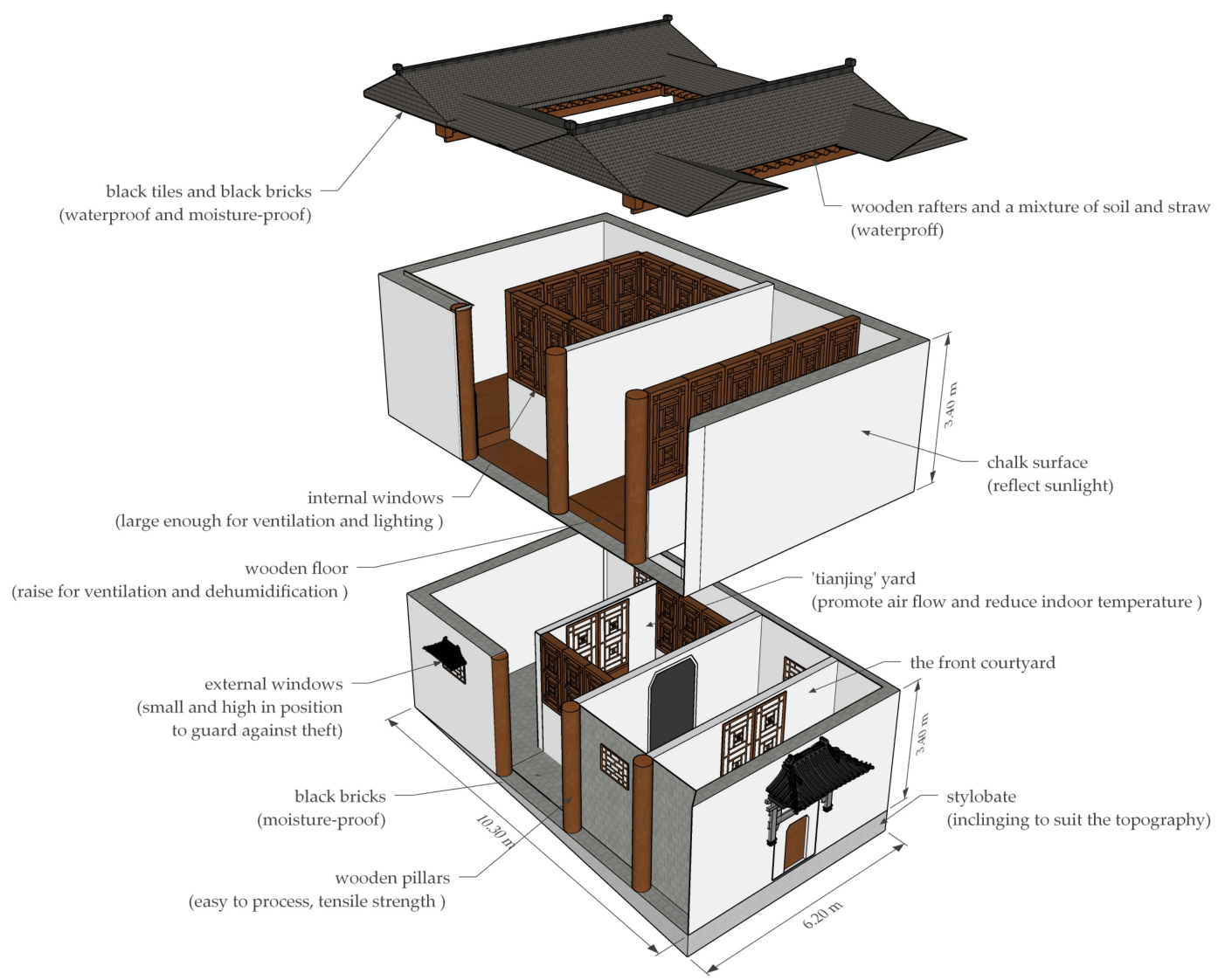

Figure 4. A sketch of the typical characteristics of the residential architectural form in the first period. (Drawn by Fengyi Ji.). 


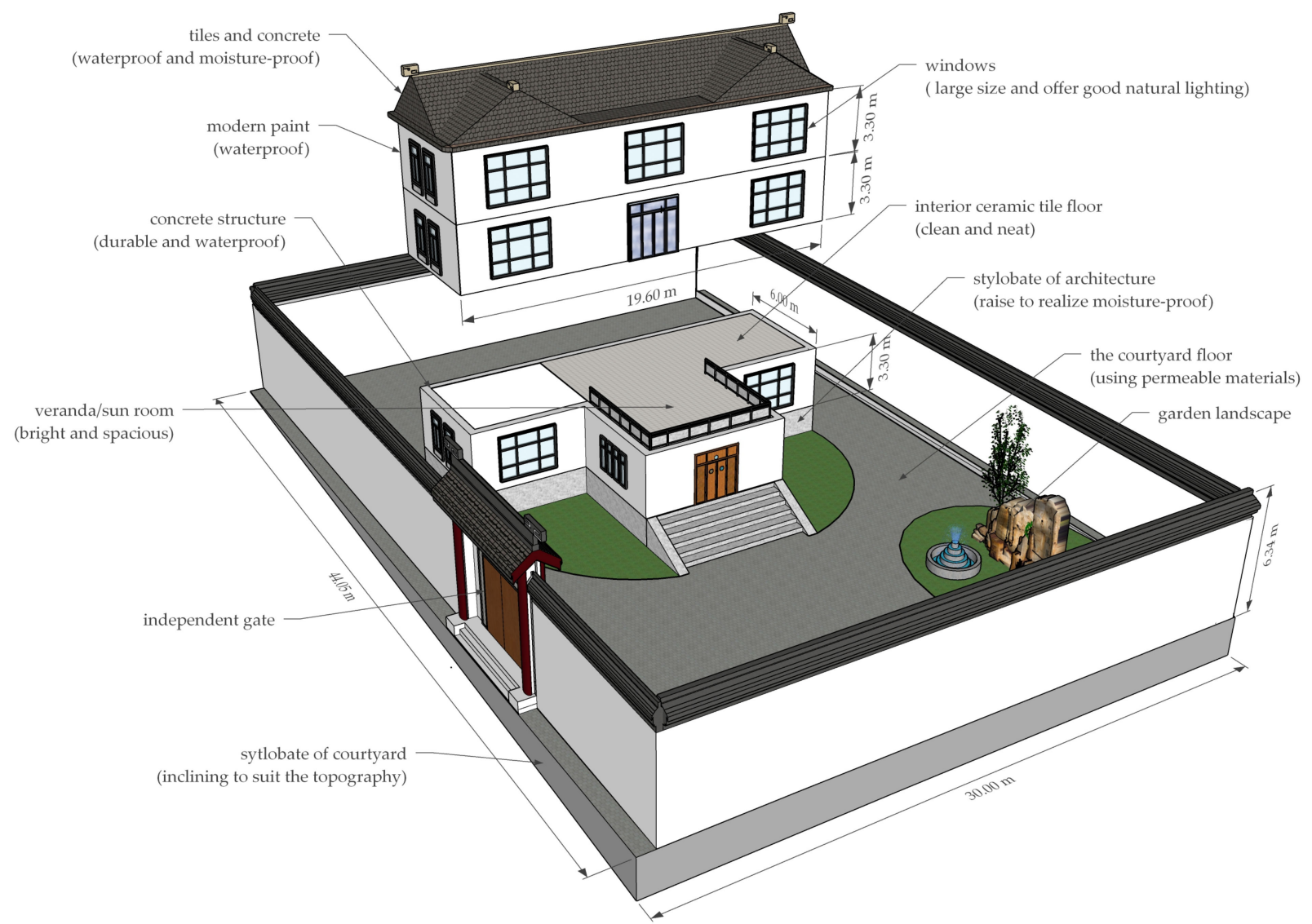

Figure 5. A sketch of the typical characteristics of the residential architectural form in the second and third period. (Drawn by Fengyi Ji.).

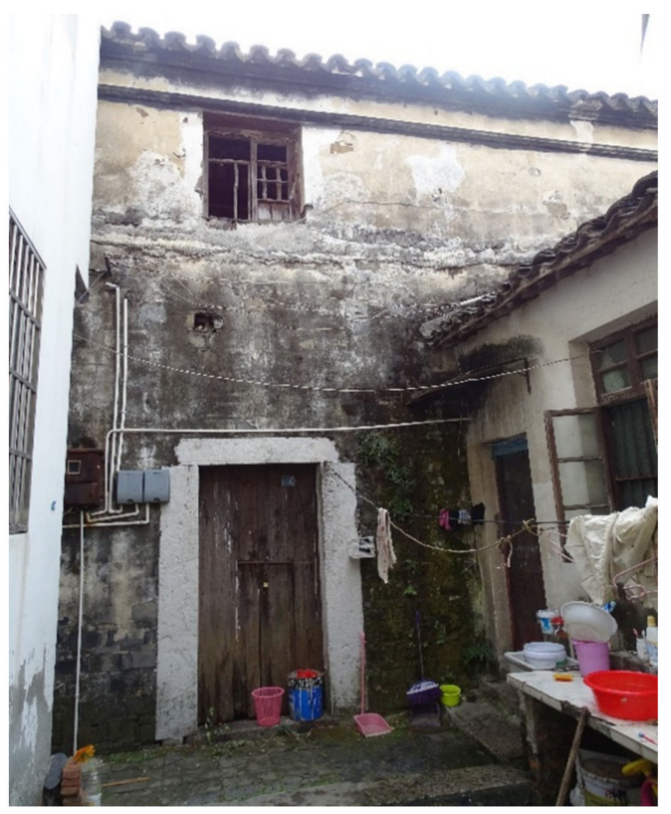

Figure 6. A Tianjing-style courtyard built in the Qing Dynasty that now belongs to three families. The three-story concrete brick architecture on the left side was built in 2000 after the original house was demolished; the single-story house on the right side was also built after the original house was demolished, but the completion time is unknown; only the traditional brick wood architecture in the middle was preserved, but it was uninhabited. (Photograph by Fengyi Ji.). 
In terms of building materials, wood and tiles were the main roofing materials that have been used to date. In the third period, they were mostly applied in antique-style architecture. Modern concrete roofs are now common. In different periods, the locals used wood as the main material of doors, windows, floors and indoor walls. After being treated, durable and moisture-proof wood was widely used and easy to shape. Black bricks and stone slate pieces were used as ground materials in the first period, which were replaced by cement outdoors and ceramic tiles indoors in the third period due to their durability. Black bricks were also the main material of exterior walls in the first period. In the second and third periods, the black bricks were replaced by red bricks with better moisture absorption and waterproofness. In the first period, white was the main colour used for the exterior walls. White exterior walls were painted with chalk to be moistureproof and reflect sunlight to increase natural light indoors. This colour scheme was called "white walls and black roof tiles" ("Fenqiangdaiwa" in Chinese). In the second period, with the lack of planning control, some locals chose colourful tiles to decorate the exterior walls of their houses. However, the architectural style of "white walls and black roof tiles" was ultimately selected in the third period by the planning commission because the white exterior walls had the function of reflecting sunlight, reducing building temperature and creating a clean and tidy visual feeling. However, the main paint on the walls changed from chalk to modern paint. The white walls were painted with modern paint with better corrosion resistance and waterproof properties. In addition, the "white walls and black roof tiles" style was also a representation of the typical architectural culture in Suzhou. Lacking planning control in the second period, diverse building materials, such as UV-blocking coated glass, plastic-steel doors and windows with good airtightness, waterproof layers in the roof, and moisture-proof layers in the building foundation, were used.

The stability of the natural environment consistently affects the purpose behind building behaviours, leading to the stable inheritance of some building habits. Changes in the socioeconomic environment, improvements in modern building technology and materials and other elements increased the choices available to residents in the specific means for responding to natural challenges.

\subsection{Complex Elements Influencing the Changing and Stable Characteristics of the Architectural Form}

Through contrastive analyses of the stable characteristics of residential architecture in different periods, the causal chains between elements that determined the change and stability of architectural characteristics form were identified (see Figure 7). The complex elements were divided into four layers, which were treated as an integrated entirety, namely, "four-layer integrated into one". First, in different periods, natural elements (climate, topography, hydrology, etc.) had a stable impact on the characteristics of the residential architectural form, which formed to meet the needs of protection from rain, moisture and heat. In the first period, the wealth in Yangwan attracted banditry, and security was threatened, leading the residential architecture to develop a form with high walls and small windows. Therefore, the residents found other means of ventilation, such as ventilation holes under walls. With the improvement in security after 1949, the windows gradually became larger to meet the needs of residents for good natural sunlight indoors and better ventilation. Consequently, the ventilation holes disappeared following the loss of their function. 


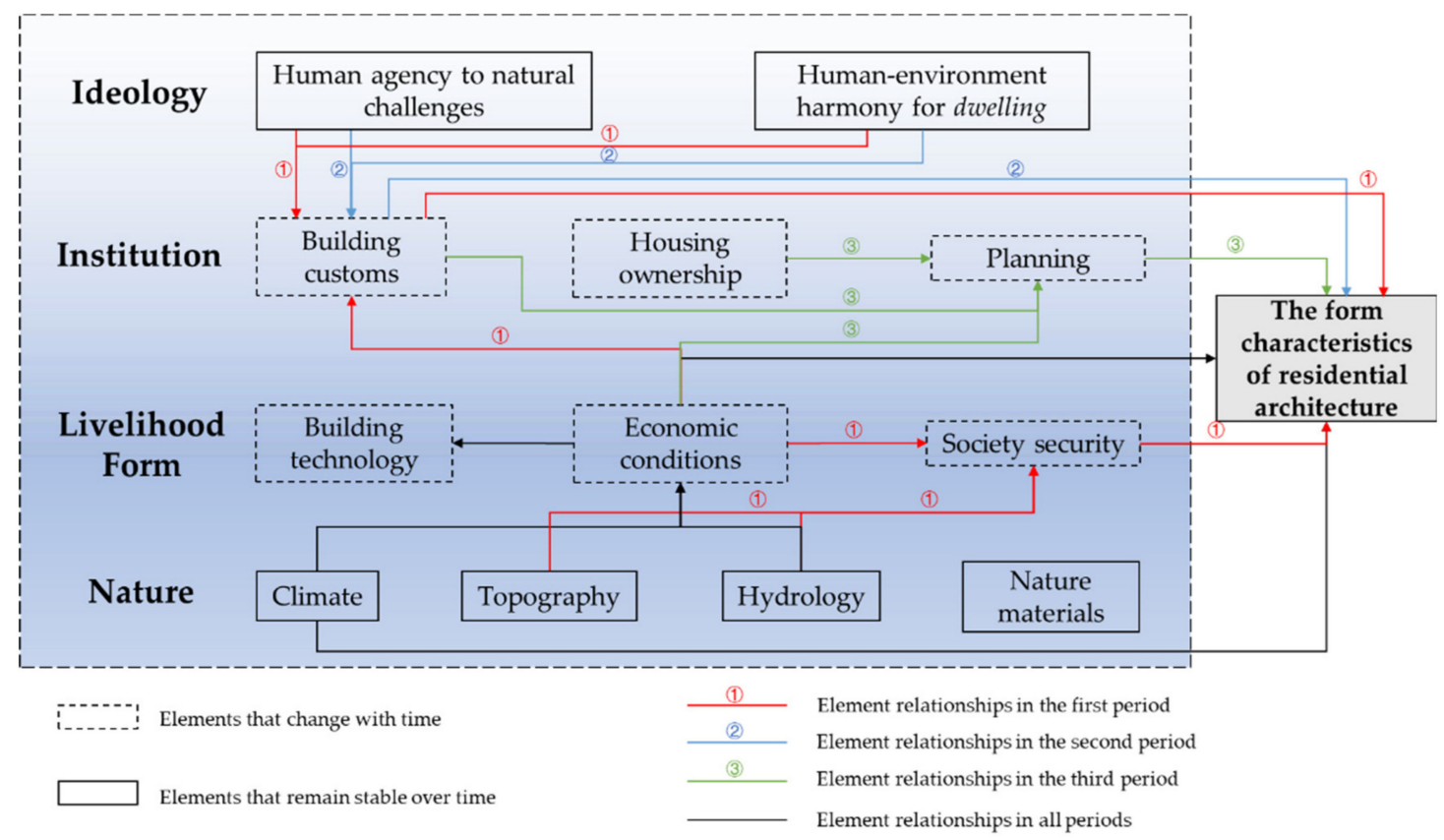

Figure 7. The complex causal chain in the framework of "four-layer integrated into one" affected architectural characteristics in different periods. (Drawn by Fengyi Ji.).

Second, the form of livelihood consistently promoted local residents' thinking and judging about the building and utilization of living space, although building technology and social and family economic situations changed a great deal. In the third period, local residents experienced great increases in income. Through the interviews, nevertheless, it was determined that the proportion of housing construction and repair costs consuming disposable income did not change significantly compared with those of the last two periods. It was found that people's willingness to pay for housing construction and repair was always limited. According to the villagers, the modern cement roof quickly solved the problem of roof leakages. However, after a long period of exposure to the sun and rain, cracks often appeared in cement roofs, even if they had been treated with waterproofing and other processes. Furthermore, such roofs were difficult and costly to replace. By comparison, traditional tile roofs were easy and affordable to replace. Local residents ultimately combined the old and new materials to build a roof structure with tile as the outer layer and cement, bricks and rafters sequentially as the lower layer. The combination of cement and tiles was effective in rainy weather and met the actual needs of the residents.

Third, ideology represents a human initiative to address natural challenges and create harmonious human-environment interactions. Ideological elements remained stable in the different periods. Through building customs, these two elements impacted the characteristics of residential architecture in the first and second periods. Institutions, including building customs, housing ownership and rural planning, comprised the Secondness of Habit and changed among the different periods. The building customs related to the preferences of residents changed with economic conditions, influencing the architectural characteristics in the different periods. Nevertheless, the connection between ideological elements and residential architecture was severed in the third period and replaced with strict planning for protection and development. The problem of housing ownership limited the scope of the planning's influence. Some architecture with housing ownership disputes represented residents' resistance to planning implementation. Economic development was the most important reason for the emergence of protection and development planning in Yangwan. The planning regulations for residential architecture, such as "white walls and black roof tiles" and "elegant colours", reflected the planners' understanding of the building customs in Yangwan. Therefore, strict planning was not simply an abstract concept. 
To some extent, it was conducive to maintaining the inheritance of some characteristics of the traditional residential architecture form. However, it ignored the emotional connection between humans and the material space, and residents lost their ability to freely change building techniques to cope with natural challenges. In real life, the emotional connection between humans and their material living space still contributed to the inheritance of building habits. As residents became familiar with the house they lived in for a long time, the material house served as a form of emotional sustenance for them and became "home" [54].

As a "home", the house provided residents with a protective space isolated from the external environment. The residents would take the initiative to care for and repair their houses and refuse to move, which was an important way to inherit some building habits. No. 96, Zhangxiang, Yangwan, was built during the Qing Dynasty. At the time of fieldwork, there was only one elderly man living there; he was alone, without any children or savings. He was unable to repair the dilapidated house, but he kept the interior space tidy. The old man rejected the village cadres' proposal to move to the home for the aged and let the government care for the house. He said, "This is my home. I'm used to living here".

Another example was No. 23, Group 9, Shangwan, Yangwan, which was also built in the Qing Dynasty. It used to have a single story and three Tianjing yards, but due to ownership, only one old Tianjing yard and a newly built courtyard were still in use. The resident, Mr. Ju, was well-off. He stated that "My parents have always lived here", "The old house is close to Lake Tai and it is comfortable for humans to live" and "It is a good place for children on holiday". Thus, Mr. Ju chose to constantly renovate and maintain the old architecture. However, the cost of renovating the old house was more than building a new modern house with three stories. Mr. Ju retained the original black bricks and wooden columns of the traditional architecture and treated them with modern anti-insect and anti-corrosion treatments. The old wooden walls were changed to brick walls, with thicknesses varying from $15-18 \mathrm{~cm}$ to approximately $25 \mathrm{~cm}$, to make the structure stronger and reduce the influence of the outside environment. The rotten wooden floors in the bedroom were replaced with a modern anti-insect and anti-corrosion wooden floor with a height of $25 \mathrm{~cm}$ to realize better moisture protection and ventilation functions. To prevent dust or rainfall from cracks in the roof, a ceiling was set inside. A rainwater collecting device was installed under the eaves to prevent rainwater from dripping on people. For safety reasons, the original windows were small, and the indoor lighting was very poor. Now, the original small wooden windows were abandoned in the process of repair, and the transmission of light was improved with glass windows. The size of the windows was greatly expanded to meet the needs of residents for sufficient indoor natural lighting.

In summary, human beings have always played an active role in responding to natural challenges. Although elements in the form of livelihood and ideology changed over the three periods, people continued to retain useful building habits to address the natural environment and pursue harmonious human-environment interactions through constant thinking, judging and re-selecting building habits. During the ongoing process of thinking, judging and re-selecting, the residents realize dwelling. Furthermore, modern technology and materials are applied to help residents repair and care for their houses so that they can live better during dwelling.

Through Figure 7, we can also understand the logic behind the characteristics of residential architectural forms in different periods by taking time as the starting point and focusing on the change and stability in the "four-layer integrated into one" concept. Taking the Ming and Qing Dynasty buildings of the first period as an example, first, the natural elements affected the livelihood form in Yangwan. They influenced the combined characteristics of the architectural form. The climate had a direct impact on architectural characteristics, such as the "white walls and black roof tiles" style and large building massing (Firstness of Habit). The warm and rainy climate determined the diverse types and high production of local crops, which served as a basis for the development of commercial activities. Convenient communication via land and water also helped the commodity 
economy prosper. Local building technology (Secondness of Habit) was promoted by good economic conditions. Because there was a demand for building in economically prosperous areas, which could also provide funds for building, an organization of craftsmen, Xiangshan Bang (Xiangshan Gang), emerged in the Suzhou area; these craftsmen were good at complex and fine building work (Secondness of Habit). This organization further promoted the development of local building technology. Yangwan is surrounded by Lake Tai on three sides, and such topographical and hydrological conditions attracted banditry, causing security risks (Secondness of Habit). Therefore, high walls with small windows were applied to improve the anti-theft function of houses (Firstness of Habit). In addition, the economic condition of families directly influenced the residents' choice of some architectural features (Firstness of Habit); for instance, extended families tended to build larger and more decorative houses with multiple Tianjing.

Second, the livelihood form affected the institutional elements, and they had a common influence on architectural characteristics. The local economic conditions also affected building customs, such as the use of silver ingots, coins, deer, carp, writing brushes and other decorative patterns (Firstness of Habit). These patterns not only embodied people's longing for a better life (Secondness of Habit) but also reflected the coexistence of a prosperous commodity-based economy and farming culture. Moreover, many building customs were formed to ensure the safety and prosperity of the family (Secondness of Habit), such as the odd number of horizontal rooms and adjacent houses of the same height. There were also many important rituals conducted at the main building stages, including the beginning of construction and the installation of the beam and the ridge. Economic development also improved people's adaptability to the natural environment (Thirdness of Habit). For example, we found that the traditional residential architecture in Yangwan was normally located at an average elevation of more than $10 \mathrm{~m}$, which was much higher than the highest water level of Lake Tai in history (5.07 m, in 1999 [55]). This was the traditional way to adapt to flood disasters (Secondness of Habit). However, with the improvement of flood resistance devices, some new architecture has now been built on the edge of Lake Tai (Firstness of Habit).

Finally, the elements of ideology affected the elements of the institutions, and they had a combined effect on the architectural characteristics. During this period, due to low productivity, people emphasized improvements in building technology to address the natural challenges of the outside world and create a liveable space rather than transforming the natural environment. Residents also participated in the building process during this period, constantly repairing and transforming their houses as they interacted with the natural environment. Finally, new characteristics (Firstness of Habit) were created by people in the process of thinking and judging (Thirdness of Habit). During this process, dwelling was realized, and the emotional connection between humans and material space was established.

\section{Discussion and Conclusions}

Based on the above analysis, three main conclusions are reached.

First, dwelling is realized in the process of humans' active communication with the material space of architecture. Only when architectural protection shifts its focus to the wisdom of people in addressing natural challenges and to daily life can humans and the natural environment live in harmony, and then material space will gradually gain significance and vitality through constant thinking, judging and choosing. This complete process is the Thirdness of Habit, which is the process of realizing dwelling, but it has been ignored because of improvements in modern technology. Through a comparison of the characteristics of the residential architectural form in Yangwan among the three periods, it has been noted that although the livelihood form and institutional elements have changed, people continue to think about and actively respond to natural challenges (Thirdness of Habit). The purposes of buildings in the different periods were always to avoid moisture, rain and heat mainly. Therefore, the stable element in the change was dwelling, which 
represented harmonious human-environment interactions and connected humans with material space.

The Thirdness of Habit determines whether building habits change or are maintained. The Thirdness of building habits, formed through long-term interaction with the natural environment, is the realization process of dwelling. By participating in the building process and constantly caring for a house, residents gradually form new building habits that serve as the rules for building (Secondness of Habit) and establish an emotional connection with the material space through long-term interactions. People also reassess the practical value of traditional architectural characteristics through constant thinking, judging and actively responding to natural challenges (Thirdness of Habit). Finally, the residents choose to inherit or change building habits, and old characteristics remain or new characteristics form (Firstness of Habit). Then, a harmonious relationship between humans and nature in a changing environment is developed in the process of realizing dwelling. The process of continuous interaction between humans and nature and humans' constant thinking about nature is the process of realizing dwelling. Harmonious human-environment interaction is the core of dwelling, the core of sustainable residential architecture culture, and the fundamental reason for the characteristics of traditional residential architectural form. The essence of the protection of traditional residential architecture is not the physical form of the architecture but the process of dwelling in a time and space of change. It is also a process of continuously reflecting and developing.

Second, the relative stability of the "four-layer integrated into one" concept promotes the inheritance of building habits and the characteristics of traditional residential architecture. According to our analysis, the elements of the natural environment and ideology changed little, and their influences on the residential architectural form in Yangwan were stable in all three periods. The residents inherited the building habits and the characteristics of the architectural form that addressed natural conditions such as undulating terrain and a hot, rainy and humid environment. The constantly changing elements of livelihood forms and institutions encouraged local residents to reflect upon and reselect building habits. In addition, people took the initiative to address the challenges of the natural environment, which promoted their caring and repair behaviour. This spirit preserved the interaction between people and the material space, which is also the process of dwelling realization. The relative stability of the "four-layer integrated into one" concept in the first and second periods also led to their consolidation. Nevertheless, in the third period, although village planning avoided a change in building habits to some extent, it also disrupted the interaction between residents and the material space. The unified regulation also limited the architectural characteristics available to residents to select from and hindered the development of building habits in daily practice. When official power cut off the emotional connection between people and architecture, residents ceased to demonstrate care; they could no longer actively inherit or apply their thoughts to building habits (Thirdness of Habit). The cyclic evolution was cut off. In the fieldwork, it was found that the residents did not deeply understand the meaning behind the planning goal to limit changes in architectural characteristics. Instead, through the interviews, it was found that they summarized the planning as "protecting tradition" in the literal sense, with no meaning, and expected more benefits from it.

Third, dwelling and the Thirdness of Habit should be the core of the protection and renewal work of traditional residential architecture, rather than the simple goal of retaining the physical form of buildings through one unified approach. Such an approach will help people think critically about the building practices involved in protection and renewal. What is applicable to different regional spaces is not the architectural physical form; it is the traditional spirit with which human beings actively address natural challenges and respect harmonious human-environment interaction. This spirit encourages people to constantly think and judge and contributes to the cyclic evolution of building habits (Thirdness of Habit). On the one hand, harmonious human-environment interaction is the core of dwelling and the key to the sustainable development of traditional residential architecture. It can 
work as a standard for evaluating the rationality of local residential architecture. On the other hand, in the process of building and caring for houses, human beings are constantly pursuing better building habits to cope with natural challenges. The emotional connection between human and material space is maintained during that process. This is also the realization process of dwelling and the embodiment of the Thirdness of Habit. Through this new perspective, the essence of building habits and the logic behind the characteristics of traditional residential architecture can be found. It contributes to the advancement of human-environment interactions and promotes the active development of architectural characteristics.

This study also provides practical guidance for the government. The question of whether traditional characteristics can be changed should be considered first in regard to protection planning and regulations rather than simply and uniformly stipulating all the characteristics. In this way, it can avoid official protection planning from ignoring the actual situation, pursuing excessive renewal and neglecting traditional characteristics. It will contribute to prioritizing the allocation of financial resources for the protection of traditional residential architecture. In future practice, architectural characteristics chosen to address the local natural environment should be the main focus of protection and renewal to realize dwelling. Taking Yangwan as an example, the characteristics of the residential architectural form should focus on waterproof, moisture-proof and heatproof qualities. On the premise of respecting these characteristics, we should update the interior of the traditional houses to adapt to a modern lifestyle, such as installing clean kitchen and bathroom facilities, replacing traditional building materials with better rainproof and heat insulation, and so on. Keeping these qualities will contribute to the protection of the traditional architectural form. What planning should ban are characteristics blindly applied to embody wealth and that do not conform to the local natural conditions, rather than depriving residents' right to spontaneously repair their houses. Residents should be allowed to and encouraged to participate in the process of building and repairing their houses. An emotional connection and communication between human beings and the material space can be established through practice and experience. In this way, people will be more willing to spontaneously protect and update residential buildings. Although traditional residential architecture was built in the past, it is constantly updated through the thoughts and judgements of every generation.

Some study gaps can be addressed by future work. The characteristics of the traditional architecture form we can observe today have been affected by the building techniques and the specific aesthetic orientation of historical times, which makes residential architecture a general display of an actual situation and a specific product of a certain period. Therefore, this article cannot show every attitude of human beings towards natural challenges in the past. In addition, the challenge of balancing the historical and cultural value of traditional residential architecture with the ownership of residents has not yet been addressed. At present, many of the original villagers in Yangwan have moved away, leaving the old architecture to decay. These residents have their own considerations and are not willing to relinquish their ownership and management rights to their house to the relevant government departments. Coordinating the use of traditional residential architecture and the rights and interests of residents is a problem that should be further discussed in the future.

Author Contributions: F.J. conducted the fieldwork, collected the first-hand data, and wrote the major parts of the article. S.Z. wrote some parts of this article and provided valuable and important suggestions. All of the figures in this article were photographed or drawn by F.J. All authors have read and agreed to the published version of the manuscript.

Funding: This research was funded by the National Natural Science Foundation of China, the grant number 41771148. The APC was funded by Beijing Normal University.

Institutional Review Board Statement: Not applicable.

Informed Consent Statement: Informed consent was obtained from all subjects involved in the research. 


\section{Data Availability Statement: Not applicable.}

Acknowledgments: We truly appreciate everyone who participated in the fieldwork in Yangwan. We would like to thank the associate editor and anonymous reviewers for helping us improve the manuscript.

Conflicts of Interest: The authors declare no conflict of interest.

\section{References}

1. Patrascu, G. Vernacular heritage in Romania. In Futuropa; Palmer, R., Thérond, D., Eds.; Bietlot-Gilly: Theux, Belgium, 2018; pp. 14-15. ISSN 1998-1457.

2. ICOMOS. ICOMOS Charter-Principles for the Analysis, Conservation and Structural Restoration of Architectural Heritage. 2003 Available online: https://www.icomos.org/images/DOCUMENTS/Charters/structures_e.pdf (accessed on 22 January 2021).

3. Bagchee, A. Vernacular Architecture of Handloom Sari Weavers in India: A Case for Conservation of Traditional Houses and Settlements of Handloom Weavers' Clusters. J. Heritage Manag. 2018, 3, 1-26. [CrossRef]

4. Buchecker, M. Withdrawal from the Local Public Place: Understanding the Process of Spatial Alienation. Landsc. Res. 2009, 34, 279-297. [CrossRef]

5. Kırbaş, B.; Hızlı, N. Learning from Vernacular Architecture: Ecological Solutions in Traditional Erzurum Houses. Proc. Soc. Behav. Sci. 2016, 216, 788-799. [CrossRef]

6. Bianco, L. Rural and Urban Vernacular Architecture of the Mediterranean: A source for contemporary, contextual, architectural design solutions. In Proceedings of the 5th Electronic International Interdisciplinary Conference, Online, 8-12 August 2016; EDIS-Publishing Institution of the University of Zilina: Zilina, Slovakia, 2016; Volume 5, pp. 126-131.

7. Federal Emergency Management Agency. The History of Building Elevation in New Orleans. 2012. Available online: https:/ / www.crt.state.la.us/Assets/OCD/hp/uniquely-louisiana-education/Disaster-Recovery/The \%20History\%20of $\% 20$ Building\%20Elevation\%20in\%20New\%20Orleans\%2012-21-12.pdf (accessed on 22 January 2021).

8. Silva, K.D. Resettlement Housing Design: Moving Beyond the Vernacular Imagery. 2011. Available online: https: / / kuscholarworks.ku.edu/bitstream/handle/1808/15270/Silva_2011_Resettlement.pdf?sequence=1\&isAllowed=y (accessed on 8 May 2021).

9. Edwards, J.D. Creole Architecture: A Comparative Analysis of Upper and Lower Louisiana and Saint Domingue. Int. J. Hist. Archaeol. 2006, 10, 237-267. [CrossRef]

10. Ara, D.R.; Rashid, M. Tracking local dwelling changes in the Chittagong Hills: Perspectives on vernacular architecture. J. Cult. Geogr. 2016, 33, 229-246. [CrossRef]

11. Gorączko, M.; Gorączko, A. Vernacular architecture and traditional rural landscape in new socio-economic realities: A case study from Central Poland. Bull. Geogr. Socio Econ. Ser. 2015, 30, 43-58. [CrossRef]

12. DeMeritt, D. The nature of metaphors in cultural geography and environmental history. Prog. Hum. Geogr. 1994, 18, 163-185. [CrossRef]

13. Barrera, M.D.; Gil-Crespo, I.; Maldonado-Ramos, L. Historical development and environment adaptation of the traditional cave-dwellings in Tajuña's valley, Madrid, Spain. Build. Environ. 2014, 82, 536-545. [CrossRef]

14. Bodach, S.; Lang, W.; Hamhaber, J. Climate responsive building design strategies of vernacular architecture in Nepal. Energy Build. 2014, 81, 227-242. [CrossRef]

15. Convertino, F.; Di Turi, S.; Stefanizzi, P. The color in the vernacular bioclimatic architecture in Mediterranean region. Energy Procedia 2017, 126, 211-218. [CrossRef]

16. Nguyen, P.A.; Bokel, R.; Dobbelsteen, A.V.D. Improving energy efficiency in Vietnamese tube houses. Smart Sustain. Built Environ. 2019, 8, 366-390. [CrossRef]

17. Goss, J. The built environment and social theory: Towards an architectural geography. Prof. Geogr. 1988, 40, 392-403. [CrossRef]

18. Philokyprou, M.; Michael, A. Environmental Sustainability in the Conservation of Vernacular Architecture. The Case of Rural and Urban Traditional Settlements in Cyprus. Int. J. Arch. Heritage 2020, 1-23. [CrossRef]

19. Mazumdar, S.; Mazumdar, S. Intergroup Social Relations and Architecture: Vernacular Architecture and Issues of Status, Power, and Conflict. Environ. Behav. 1997, 29, 374-421. [CrossRef]

20. Heidegger, M. Poetry, Language, Thought; Hofstadter, A., Ed.; Harper Colophon Books: New York, NY, USA, 1975; pp. 147-160. ISBN 06-090430-5.

21. Avriel-Avni, N.; Spektor-Levy, O.; Zion, M.; Levi, N.R. Children's sense of place in desert towns: A phenomenographic enquiry. Int. Res. Geogr. Environ. Educ. 2010, 19, 241-259. [CrossRef]

22. Latimer, J.; Munro, R. Keeping \& dwelling: Relational extension, the idea of home, and otherness. Space Cult. 2009, 12, 317-331. [CrossRef]

23. Schillmeier, M.; Domènech, M. Care and the Art of Dwelling. Space Cult. 2009, 12, 288-291. [CrossRef]

24. Seamon, D. A Geography of the Lifeworld: Movement, Rest and Encounter; Croom Helm Ltd.: London, UK, 1979; pp. 93-95. ISBN 0-85664-845-0.

25. Liu, S.; Maher, J.; Sheer, V.C. Through the eyes of older Chinese immigrants: Identity, belonging and home in a foreign land. China Media Res. 2019, 15, 39-49. 
26. Gieryn, T.F. What buildings do. Theory Soc. 2002, 31, 35-74. [CrossRef]

27. Buttimer, A. Grasping the dynamism of lifeworld. Ann. Assoc. Am. Geogr. 1976, 66, 277-292. [CrossRef]

28. Hagströmer, D. Homes in Transformation: Dwelling, Moving, Belonging. J. Des. Hist. 2011, 24, 400-403. [CrossRef]

29. Patra, R. A Comparative Study on Vaastu Shastra and Heidegger's 'Building, Dwelling and Thinking. Asian Philos. 2006, 16, 199-218. [CrossRef]

30. West, D.E.; Anderson, M. Consensus on Peirce's Concept of Habit: Before and Beyond Consciousness; Springer International Publishing: Cham, Switzerland, 2016; pp. 35-37. ISBN 978-3-319-45920-2.

31. Peirce, C.S.; Hartshorne, C.; Weiss, P.; Burks, A.W. The Collected Papers of Charles Sanders Peirce; Thoemmes Continuum: Bristol, UK, 1994; p. 2000. ISBN 978-1-855-06556-7.

32. Philokyprou, M.; Michael, A.; Malaktou, E.; Savvides, A. Environmentally responsive design in Eastern Mediterranean. The case of vernacular architecture in the coastal, lowland and mountainous regions of Cyprus. Build. Environ. 2017, 111, 91-109. [CrossRef]

33. Renping, W.; Zhenyu, C. An ecological assessment of the vernacular architecture and of its embodied energy in Yunnan, China. Build. Environ. 2006, 41, 687-697. [CrossRef]

34. Bissell, D. Virtual infrastructures of habit: The changing intensities of habit through gracefulness, restlessness and clumsiness. Cult. Geogr. 2013, 22, 127-146. [CrossRef]

35. Wicaksono, B.; Siswanto, A.; Kusdiwanggo, S.; Anwar, W.F.F. Transformation of dwelling culture based on riverine community in Musi River Palembang. In Proceedings of the 3rd International Conference on Construction And Building Engineering (Iconbuild) 2017: Smart Construction Towards Global Challenges, Palembang, Indonesia, 14-17 August 2017; AIP Publishing: Melville, NY, USA, 2017; Volume 080007. [CrossRef]

36. Lapworth, A.C. Habit, art, and the plasticity of the subject: The ontogenetic shock of the bioart encounter. Cult. Geogr. 2015, 22, 85-102. [CrossRef]

37. Datta, A. Building differences: Material geographies of home(s) among Polish builders in London. Trans. Inst. Br. Geogr. 2008, 33, 518-531. [CrossRef]

38. Dabaieh, M. Participatory action research as a tool in solving desert vernacular architecture problems in the Western Desert of Egypt. Action Res. 2013, 11, 279-298. [CrossRef]

39. Saengpanya, P.; Kintarak, A. Thailand's Floating House Project: Safe and Sustainable Living with Flooding. Int. J. Eng. Technol. 2019, 11, 299-304. [CrossRef]

40. Nabakov, P. Encyclopedia of vernacular architecture of the world. Tradit. Dwell. Settl. Rev. 1999, 10, 69-75. [CrossRef]

41. Choi, J.; Kim, Y.; Kang, J. Study on the application of vernacular design to high-rise apartment planning in Vietnam. Architect. Sci. 2013, 8, 11-18. Available online: http:/ / enapp.architw.org.tw / main/article/59.pdf (accessed on 19 June 2020).

42. Nguyen, P.A.; Bokel, R.; Dobbelsteen, A.V.D. Towards a sustainable plan for new tube houses in Vietnam. In Proceedings of the International Planning History Society Proceedings, 17th IPHS Conference, History-Urbanism-Resilience, Delft, The Netherlands, 17-21 July 2016; Carola, H., Ed.; TU Delft: Delft, The Netherlands, 2016; pp. 212-222. [CrossRef]

43. Kuleshova, M.; Semenova, T. Specific features of the vernacular habitat in Russian Culture. In Futuropa; Palmer, R., Thérond, D., Eds.; Bietlot-Gilly: Theux, Belgium, 2018; pp. 10-21. ISSN 1998-1457.

44. Bridge, G. Habit, experience and environment: A pragmatist perspective. Environ. Plan. D Soc. Space 2019, 38, 345-363. [CrossRef]

45. Tuan, Y. Space and Place: The Perspective of Experience; University of Minnesota Press: Minneapolis, MN, USA, 1977; pp. 127-128. ISBN 0-8166-3877-2.

46. López, D.; Sánchez-Criado, T. Dwelling the Telecare Home. Space Cult. 2009, 12, 343-358. [CrossRef]

47. Zhang, J.; Xu, W.; Li, A.; Zheng, K.; Zhang, J. Study on improving thermal environment and energy conservation of quadrangle adobe dwelling. Energy Build. 2016, 129, 92-101. [CrossRef]

48. Cardinale, N.; Rospi, G.; Stazi, A. Energy and microclimatic performance of restored hypogeous buildings in south Italy: The "Sassi" district of Matera. Build. Environ. 2010, 45, 94-106. [CrossRef]

49. Anna-Maria, V. Evaluation of a sustainable Greek vernacular settlement and its landscape: Architectural typology and building physics. Build. Environ. 2009, 44, 1095-1106. [CrossRef]

50. Liu, Q.; Liao, Z.; Wu, Y.; Degefu, D.M.; Zhang, Y. Cultural Sustainability and Vitality of Chinese Vernacular Architecture: A Pedigree for the Spatial Art of Traditional Villages in Jiangnan Region. Sustainability 2019, 11, 6898. [CrossRef]

51. Bissell, D. Habit Displaced: The Disruption of Skilful Performance. Geogr. Res. 2012, 51, 120-129. [CrossRef]

52. Jiangsu Provincial People's Government. Reply of the Provincial Government on the (Protection) Planning of Historic and Cultural Villages of Yangwan, Dongshan Town, Wuzhong District, Suzhou City. 2017. Available online: http:/ / www.jiangsu.gov. cn/art/2017/4/14/art_46143_2543310.html (accessed on 5 March 2020). (In Chinese)

53. Suzhou Municipal People's Government. The Protection and Development Planning of Yangwan Village, Dongshan Town, Wuzhong District, Suzhou City. 2016. Available online: http://www.suzhou.gov.cn/szsrmzf/zxghjqygh/201611/0GXZAS5W8 ZVYV03XRCOUHU7W82UWW16K.shtml (accessed on 5 March 2020). (In Chinese) 
54. Tuan, Y. Topophilia: A Study of Environmental Perceptions, Attitudes, and Values; Prentice-Hall: Englewood Cliffs, NJ, USA, 1974; p. 99. ISBN 0-231-07394-X.

55. Bureau of Archives in Suzhou. Editorial Department of Annals of Suzhou; Annals of Suzhou Guwuxuan Publishing House: Suzhou, China, 2000; pp. 24-25. ISBN 7-80574-517-X. (In Chinese) 